\title{
The Value System of Youths in Jordan: Implications for Human Resource \& Marketing Managers
}

\author{
Ahmad Mohammad Obeidat ${ }^{1}$, Zaid Mohammad Obeidat ${ }^{2} \&$ Mohammad Ibrahim Obeidat $^{3}$ \\ ${ }^{1}$ Department of Business Management, The University of Jordan, Amman, Jordan \\ ${ }^{2}$ Department of Marketing, The University of Jordan, Amman, Jordan \\ ${ }^{3}$ Department of Marketing, Amman Arabic University, Amman, Jordan \\ Correspondence: Zaid Mohammad Obeidat, Department of Marketing, The University of Jordan, Amman, \\ Jordan. E-mail: z.obeidat@ju.edu.jo
}

Received: July 25, 2016

doi:10.5539/ijbm.v11n10p162
Accepted: August 8, 2016

Online Published: September 20, 2016

\begin{abstract}
Based on a sample of 263 Jordanians, this study aimed to identify the value system of the Jordanian youths and compare it to that of their seniors. Using Rokeach value system survey and a snowball sampling technique data was collected from two samples: students in a major university in Jordan and their parents. Although, significant differences were found for a number of values between the students and their parents, the findings of this study identified similar value systems structures for both samples. This study contributes to the existing literature by exploring the value system of youths in Jordan and suggests a number of recommendations for HR and Marketing Managers.
\end{abstract}

Keywords: value system, youth, culture, Jordan, human resource

\section{Introduction}

The United Nations defines the term 'youth' as those individuals aged between 15 and 24 years. According to the latest indicators published in 2013 by the Department of Statistics in Jordan, the estimated population of Jordan (excluding Syrian refugees) was 6530000 and the number of Jordanians within the age categories (15 to 19 years) and (20 to 24 years) was 716635 and 691655 respectively. Based on these estimates, the number of Jordanian youths aged between 15 and 24 was 1408290 and thus, Jordanian youths represented $21.57 \%$ of the population in Jordan. Thompson and Arsalan (2007) Note that Jordan ranks among the world's top ten in terms of the high proportion of youth (ages 10-24) relative to other segments of the population.

According to Sparreboom and Shahnaz (2007) youths are important because of their energy, talent and creativity which constitute the foundation for the country's future development, while from a labour-market viewpoint they are important because they are expected to stay active for a long period and thus, result in high returns on investment. This suggests that (within the Jordanian context) Jordanian youths are important for both the Jordanian government and Jordanian organisations. For the Jordanian government, youths would be important because of their potential contribution to the country's economic development while for Jordanian organisations and their human resource managers, youths would be important because they represent a valuable and important source of labour. Moreover, youths are important for marketing managers because they potentially represent a considerable market segment for the products and services offered by Jordanian organisations.

Given the high percentage of youths in Jordan and the fact that they represent a considerable source of labour and at the same time a sizeable consumer market in Jordan, understanding the behaviour of these youths (either as employees/job applicants or consumers) and what shapes this behaviour would be valuable for both HR and marketing managers. Kamakura and Mazzon (1991) argue that because values are powerful explanations of human behaviour, are limited in number and are stable over time, the concepts of value and value system have been applied by behavioural scientists as predictors of consumer behaviour and organisational behaviour.

Cross cultural research examining values have noticed significant differences in the value system of the youth in the same country (Yasin, Shafqat, \& Sattar, 2011) and across different nations (e.g. Daghfous, Petrof, \& Pons, 1999). While values and the value system of youths have been explored in some countries (e.g. Do-Quyen et al, 2014), there is a dearth of research on the values and value system of youths in Jordan. Furthermore, Robbins 
and Judge (2013) note that as evidenced by several studies, Rokeach values differ among groups. Thus, this study aims to explore the value system of youths (aged between 15 and 24 years) in Jordan, and explore the extent of differences between the value system of youths and that of their seniors. Moreover, limited research attention as will be seen in the next section was given to examining the value system of youths in the Arab world and specifically in Jordan, a country faced with a number of economic and social challenges (Obeidat et al, 2016), in addition to having one of the highest unemployment rates for youth in the world (i.e. 30\%) (Obeidat, 2015). Consequently, examining the value systems of the youths in Jordan and comparing it to the older generation of Jordanians will provide valuable insights regarding the effect of these political, social, and economic pressures on the value systems of Jordanians.

Moreover, the identification of the values of Jordanian youths is useful for both HR and marketing professionals within Jordanian organisations. In relation to HR professionals, Dessler and Al Ariss (2012) note that managing and shaping the behaviour of individuals in the organisation depends on shaping the values these individuals use as behavioural guides. Thus, for HR professionals, the identification of the values of Jordanian youths can help them determine whether or not these values need shaping or if these values are already compatible with the organisations' culture. Alternatively, this information about the compatibility (or lack of) of youths' values with that of the organisation can help HR managers decide whether or not the organisation should recruit youths or direct its efforts to other segments of the society. In relation to marketers, Pride, (2008) note that values influence individuals' needs for products and while these values can change, marketers try to monitor such changes to predict changes in consumers' needs for products. In addition, Kamakura and Novak (1992) note that there has been interest among consumer researchers in the use of values as basis for market segmentation and brand preference. This paper is structured as follows; first, a review of literature examining values is provided to offer a look at some streams of research examining values. Afterwards, the methodology of this study is explained along with the process of collecting data. Finally, the results of this study are presented and discussed followed by a discussion of the implications for organisations in terms of HRM and marketing.

\section{Literature Review}

Rokeach (1968) defined a value as an individual's belief that a specific mode of conduct or end-state of existence is preferable to other modes of conduct or end-states of existence. As for value systems, Robbins and Judge (2013) note that a value system is a ranking of an individual's values according to their intensity. Values are important because according to Penn (1977) they serve as a guide to conduct. Similarly, Cileli, (2000) note that values provide the rationale for norms or rules of conduct. In relation to the importance of value systems to individuals, Kamakura and Novak (1992) argue that most life situations frequently involve conflict between values and as a result the individual will rely on his/her value system to resolve this conflict and reach a decision. Generally, according to Rokeach (1973) theory of values, values can be classified into two types, terminal values (referring to desired end states such as equality, freedom) and instrumental values (referring to modes of conduct such as honesty, politeness).

Many researchers have investigated the influence of values in a number of different fields including Marketing (Daghfous, Petrof, \& Pons, 1999), Management (e.g. Perkmann \& Spicer, 2014), and the changes in values over time (Molgat \& Larose-Hébert, 2010). Normally, due to the important influence of values on behaviour, attitudes, and changes in societies, consequently, values are essential concepts in social sciences (Schwartz, 2009; Do-Quyen et al., 2014). Furthermore, researchers also tend to agree that those beliefs normally consist of a number of values that form a system guiding the individual behavior through his/her life (Rokeach, 1973; Schwartz, 2007). Moreover, these values tend to be organized in order of priority and importance to the person and although they are flexible and might change, they often remain stable over time (Rokeach, 1973).

When looking at the literature that investigated values and value systems, a number of research themes can be noticed. The first of these focuses on examining the influence of globalization on the value system components (e.g. Afisi, 2011; Yasin, Shafqat, Sattar, 2011; George \& Uyanga, 2014). These studies suggest that the values of the society are changing due to social changes (Yasin, Shafqat, Sattar, 2011), Moral changes, (George \& Uyanga, 2014), and globalization (Afisi, 2011). Moreover, these studies suggest that youths should try to resist immoral values and be the force of change in the society, thus, generally refusing values that would change societies to the worse and accept values that would change a society for the best.

Another major stream of research has focused exclusively on examining the value system of the youths (e.g. Corney, 2004; Molgat \& Larose-Hébert, 2010; Yasin, Shafqat, \& Sattar, 2011; Thomson \& Holland, 2011; Do-Quyen et al., 2014). This stream of research found a number of results, for example; in Vietnam, it was found that students placed more emphasis on personal and political values that reflected the concern of psychological 
stability and independence. In Canada, Molgat, and Larose-Hébert (2010) found that the values of the youth are not much different from the Canadian youth 30 years ago when comparing the data they collected to previous records and reports. However, an influence of the educational level was found where people with lower educational levels tended to have stronger family values. In Britain, a longitudinal study sampling a number of youth over a period of time found that youth from rural areas appeared to have more tolerant values to immoral behaviours such as taking drugs than the youth from urban areas. However, similar to previous studies no major differences were found between the components of the value system of the youth and older generation (Thomson \& Holland, 2011). In Pakistan, using a student sample, changes were found in the value system of the youth due to globalization and social media. As a result, Yasin et al, (2011) found that the family values are changing from obedience to parents to a new form of negotiating with them. In Australia, it was found that values have a very important role in youth education and work (Corney, 2004). Although some scholars (e.g. Peng, Nisbett, \& Wong, 1997) note that comparing values between different countries tend to have a low level of validity due to used scales to measure values, a third stream of research on values tended to focus on cross-country value comparisons (e.g. Kamakura \& Mazzon, 1991; Peng, Nisbett, \& Wong, 1997; Daghfous, Petrof, \& Pons, 1999). For example, Daghfous et al, (1999) found that individual values in each country (i.e. France, North Africa) positively influence the choice intentions to adopt products according to conservative, dynamic, and hedonists values. Moreover, using Rokeach value survey, Kamakura and Mazzon (1991) found significant differences in the value system components between Brazil and the United States with more stable values for the Americans compared to the Brazilians over time. On the contrary, when comparing between the Chinese and American values, Peng, Nisbett, \& Wong, (1997) found minimal differences due to the use of the current value scales between Americans and the Chinese.

To conclude, despite the findings these studies have provided, these results are still confined to either the north or west of America (e.g. Canada, United States, Brazil), Europe (e.g. Britain), and Asia (e.g. Vietnam, Pakistan), with no studies examining the value system components of the youth in the Middle East and specifically in Jordan. Furthermore, Jordan, surrounded by a number of conflicts in neighbor countries (e.g. Egypt, Iraq, Palestine/Israel, Syria), is now faced with a number of economic and humanitarian crises as a result of the increasing number of refugees and the pressure they place on the infrastructure (Obeidat et al., 2016). Consequently, identifying the value system components of the Jordanian youth and seniors could provide an insight if these values are affected as a result of these challenges. Moreover, as seen in previous studies, all comparative studies examining the value system components used a methodology of either collecting data from the same respondents over time (e.g. Thomson \& Holland, 2011), comparing between different youth groups (Do-Quyen et al., 2014), different countries (Kamakura \& Mazzon, 1991), or by comparing between the youth and senior groups by collecting data from a younger sample and comparing it to previous studies or reports that examined the old (e.g. Molgat \& Larose-Hébert, 2010). As a result, this study attempts to provide new insights by using a sample of students and their parents and comparing the results.

\section{Methodology}

Considering that this study attempts to identify and explore the youth value system in Jordan and compare it to their parents, this study adopts a descriptive survey approach. Employing this approach here appeared to be more appropriate considering that this study aims to understand the underlining mechanisms of youth value system and compare two samples (Bryman \& Bill, 2015). In alignment with the purpose of this study, the study population consisted of youths and seniors (i.e. their parents). Because undergraduate students provide a good representation of youths and their respective parents provides a good representation of an older population, a sample was drawn from each group for the purposes of this study. Consequently, a snowball sampling method was used resulting in a total of 263 respondents $(\mathrm{N}=263)$. The older senior sample consisted of 114 respondents while the youth sample consisted of 149 respondents all of whom completed the survey. The data was collected using students from the University of Jordan, each student participant received two copies of the survey, one to be filled by the student in class, and one to be handed to one of his/her parents to complete and then hand back to the student to return back to the researcher. Moreover, $53.8 \%$ of respondents were male, $55 \%$ were below the age of $25,75 \%$ held a bachelor degree, and $47 \%$ of respondents had an income level below $500 \mathrm{Jds}$.

To identify and measure the value systems of respondents, the Rokeach's Value Survey (Rokeach, 1973) was used. This survey consists of two types of values, instrumental (18 items/values) and terminal (18 items/values) accompanied by a short description of the meaning of each value. Each respondent was asked to rank the values in each set in terms of their importance to him/her in his/her daily life (from 1: most important to 18: least important). Furthermore, the simplicity of this instrument where each person is only asked to rank these values in order of importance makes it the most popular theory on values to date and the most used by researchers 
(Do-Quyen et al., 2014). Lastly, respondents were asked to provide demographic data (e.g. gender, age, education, and income level). A pilot study was conducted before the actual data collection began. This was done to allow the researchers to resolve any difficulties the participants might have with the survey questions and it consisted of 5 students from a major university in Jordan. However, no issues relating to the wording, length, or the content of the questions were raised. Finally, a back translation method was used to translate the questions from English to Arabic which eliminates any bias in the translation process and maintains the best match between the source translation and the target translation (Saunders et al, 2007).

\section{Findings \& Discussion}

Table 1. Instrumental values

\begin{tabular}{llllll}
\hline Value & Senior sample & & Youth sample & & Rank \\
& Mean & Rank & Mean & Sig \\
\hline Ambitious & 5.91 & 3 & 6.9 & 3 & .060 \\
Broad-minded & 9.06 & 8 & 9.01 & 7 & .936 \\
Capable & 11.2 & 13 & 10.73 & 13 & .350 \\
Cheerful & 11.42 & 15 & 10.55 & 10 & .140 \\
clean & 4.71 & 2 & 5.53 & 1 & .072 \\
Courageous & 8.29 & 5 & 7.34 & 4 & .113 \\
Forgiving & 3.46 & 1 & 5.62 & 2 & .001 \\
Helpful & 11.04 & 11 & 10.67 & 12 & .551 \\
Honest & 11.77 & 16 & 8.77 & 6 & .000 \\
Imaginative & 7.93 & 4 & 9.06 & 8 & .076 \\
Independent & 11.31 & 14 & 10.66 & 11 & .258 \\
Intellectual & 11.92 & 17 & 12.12 & 18 & .695 \\
Logical & 8.33 & 6 & 8.31 & 5 & .974 \\
Loving & 10.79 & 10 & 11.31 & 16 & .359 \\
Obedient & 11.07 & 12 & 10.77 & 14 & .574 \\
Polite & 10.11 & 9 & 11.18 & 15 & .058 \\
Responsible & 8.62 & 7 & 9.79 & 9 & .068 \\
Self-controlled & 13.29 & 18 & 11.58 & 17 & .005 \\
\hline
\end{tabular}

In relation to data analysis, SPSS was used to calculate the frequencies and mean rankings of the values. In addition, an Independent sample t-test was conducted to compare between the two samples. In relation to interpreting mean scores, given that respondents were asked to rank these values according to their importance from (1: most important) to (18 least important), a low mean score would indicate higher importance than a high mean score. As seen in Table 1 for the instrumental values (please refer to appendix for full table) between the senior and youth samples, the most important instrumental values reported by the senior sample were "forgiving, clean, ambitious, and imaginative", seeing as they had the lowest means scores (Do-Quyen et al., 2014). Moreover, the least important instrumental values were "self-controlled, intellectual, honest, and loyal". For the youth sample, the most important values were "clean, forgiving, ambitious, and courageous" and the least important were "intellectual, self-controlled, loving, and polite". Looking at the results, this means that both samples tend to focus on intrinsic values that the respondents wish to have instead of accomplishment values. Finally, an independent sample t-test was conducted to compare between the two groups in term of these instrumental values and significant differences were found only for three values (i.e. forgiving, honest, and self controlled) as seen in Table 1. With the mean scores for the forgiving value being significantly higher for group 2 (i.e. youth sample) with $(\mathrm{M}=5.62, \mathrm{SD}=4.06)$ than group 1 (i.e. senior sample) with $(\mathrm{M}=3.46, \mathrm{SD}=5.8)$. For the honest value, the mean scores were also significantly higher for group 2 (i.e. youth sample) with $(\mathrm{M}=11.7, \mathrm{SD}=$ 4.93) than group 1 (i.e. senior sample) with $(\mathrm{M}=8.77, \mathrm{SD}=5.39)$. For the self controlled value, the means scores for group 2 were also significantly higher for group 2 (i.e. youth sample) than group 1 (i.e. senior sample) with $(\mathrm{M}=13.2, \mathrm{SD}=4.42)$ and $(\mathrm{M}=11.5, \mathrm{SD}=5.43)$.

Furthermore, for the value system in terms of terminal values as seen in Table 2, the findings show that the most important values for the youth sample were "family security, mature love, happiness, and a comfortable life". Similarly, for the senior sample the most important values were "mature love, a world at peace, family security, and self respect". In terms of the least important values for youth sample, the participants noted "salvation, true 
friendship, national security, and wisdom". For the senior sample, "salvation, true friendship, national security, and equality" were similarly the least important values. These results tend to show a similarity between both samples in that they tend to reflect intrinsic and social/political values that tend to serve their self interest in addition to a family orientation.

Table 2. Terminal values

\begin{tabular}{|c|c|c|c|c|c|}
\hline \multirow[t]{2}{*}{ Value } & \multicolumn{2}{|c|}{ Senior sample } & \multicolumn{3}{|c|}{ Youth sample } \\
\hline & Mean & Rank & Mean & SD & Sig \\
\hline A comfortable life & 9.31 & 10 & 8.42 & 4 & .104 \\
\hline Equality & 11.52 & 15 & 9.080 & 7 & .000 \\
\hline Exciting life & 10.64 & 13 & 10.36 & 14 & .623 \\
\hline Family security & 7.54 & 3 & 6.68 & 1 & .183 \\
\hline Freedom & 10.80 & 14 & 9.20 & 9 & .010 \\
\hline Happiness & 9.73 & 12 & 7.46 & 3 & .001 \\
\hline Inner harmony & 9.12 & 8 & 9.087 & 8 & .956 \\
\hline Mature love & 4.52 & 1 & 7.26 & 2 & .000 \\
\hline National security & 11.74 & 16 & 10.93 & 16 & .032 \\
\hline Pleasure & 8.98 & 6 & 9.32 & 10 & .575 \\
\hline Salvation & 12.24 & 18 & 12.4 & 18 & .650 \\
\hline Self respect & 8.35 & 4 & 8.95 & 6 & .331 \\
\hline A sense of accomplishment & 8.85 & 5 & 10.20 & 12 & .028 \\
\hline Social recognition & 9.42 & 11 & 10.25 & 13 & .191 \\
\hline True friendship & 12.17 & 17 & 11.28 & 17 & .130 \\
\hline Wisdom & 9.07 & 7 & 10.52 & 15 & .017 \\
\hline A world at peace & 8.80 & 2 & 7.33 & 5 & .021 \\
\hline A world of beauty & 9.18 & 9 & 10.19 & 11 & .132 \\
\hline
\end{tabular}

Moreover, as seen in Table 2, the results of the independent sample t-test show significant differences for 7 values (i.e. equality, freedom, happiness, mature love, national security, a sense of accomplishment, wisdom, and a world at peace). For equality, the mean score for groups 1 (i.e. senior sample) was significantly higher than the second group with $(\mathrm{M}=11.5, \mathrm{SD}=4.48)$ and $(\mathrm{M}=9.08, \mathrm{SD}=4.79)$. For the freedom value, the mean score for groups 1 (i.e. senior sample) was also significantly higher than the second group with $(\mathrm{M}=10.8, \mathrm{SD}=4.91)$ and $(\mathrm{M}=9.02, \mathrm{SD}=5.03)$. Moreover, for the national security value, the mean score for groups 1 (i.e. senior sample) was significantly higher than the second group with $(\mathrm{M}=11.7, \mathrm{SD}=4.92)$ and $(\mathrm{M}=10.3, \mathrm{SD}=5.1)$. For the happiness value, the mean score for group 2 (i.e. youth sample) was significantly higher with $(\mathrm{M}=7.26, \mathrm{SD}=$ 5.22) and $(\mathrm{M}=4.52, \mathrm{SD}=5.011)$ for group 1 (i.e. senior sample). For the sense of accomplishment value, the mean score for group 2 (i.e. youth sample) was significantly higher with $(\mathrm{M}=10.2, \mathrm{SD}=4.7)$ and $(\mathrm{M}=8.8, \mathrm{SD}=$ 5.07) for group 1 (i.e. senior sample). Similarly, for the wisdom value the mean score for group 2 (i.e. youth sample) $(M=10.5, S D=4.89)$ was significantly higher than group 1 (i.e. senior sample) $(M=9.07, S D=7.33)$. Finally, for the world at peace value, the mean score for group 1 (i.e. senior sample) $(M=8.80, S D=5.41$ ) was also significantly higher than group 2 (i.e. youth sample) $(\mathrm{M}=7.33, \mathrm{SD}=4.78)$.

Both Tsang (1993) and Cileli and Tezer (1998) also found that in China and Turkey traditional family values were still dominant for the youth in their countries and ranked family security very highly. Generally, for instrumental values these results show that both samples have a preference for internal values that the samples wish to have instead of accomplishment values. Moreover, in terms of terminal values, the results also show that both samples tend to choose values that reflect and served their self interest from a social and political perspective. Cileli (2000) also found that the value orientations of the Turkish youth were somewhat leaning toward an individualistic and competitive orientation. However, in this study in terms of the terminal values there also seems to be an orientation towards family. Moreover, these findings are also in line with some previous findings in the literature which shows that minimal differences exist between the younger and older generation value system components. For example, the study of Molgat and Larose-Hébert (2010) in Canada showed that the values of the Canadian youth didn't differ significantly from older generation. Similarly in Britain, the study of the Thomson and Holland (2011) also showed that the values of youth in Britain were similar to the older generation. Consequently, these findings tend to show that certain values sometimes tend to 
be transferrable from the older generations to younger ones.

Generally, despite the similarity of the value systems between the youth and the senior samples as seen in the previous section, some significant differences were found regarding some values. For example, the youth sample scored higher mean scores for the forgiving, honest, and self controlled values. Considering that these values are instrumental (i.e. preferred modes of conduct), this result could show that youth in Jordan prefer to be forgiving, honest, and have a better self control more than the senior sample. Feather (1975) also states that parents tend to have more conservative values such as national security and a world at peace, whereby, youth are more likely to adopt pleasure and exciting values that enhance friendship. This finding could also mean that due to their younger age and more temperament, the youth in Jordan wish to possess these values more than the seniors who could already have these values shaped in their behaviors due to their age and experience in life. Moreover, in terms of terminal values (i.e. the preferred end state of conduct) the disparity between the two samples is much bigger. For example, for the national security, equality, a world at peace, and Freedom values, the seniors in Jordan had higher mean scores than the youth sample. This finding could also be explained by the current state of political and social unrest surrounding Jordan and the large number of refugees coming to Jordan (Obeidat et al, 2016) which might cause a bigger awareness levels for older generation of the importance of security, freedom and equality, and a world at peace. In addition, seniors tend to have more conservative values (Feather, 1975). Furthermore, in terms of the terminal values of "Happiness, sense of accomplishment, Wisdom", the mean scores of these values for the younger generation was higher than the senior sample as seen by the result of the T-test. This finding could mean that the youth in Jordan place higher regard for happiness. Feather, (1975) also found that youth are more likely to adopt pleasure and exciting values due to their age. Additionally, in terms of the sense of accomplishment and wisdom values, the youth could place more emphasis on work and accomplishment values more than seniors due to their young age (Molgat \& Larose-Hébert, 2010; Kristiansen \& Zanna, 1994) and lack of wisdom and impulsiveness.

\section{Conclusions \& Managerial Implications}

To conclude, based on a sample of $(\mathrm{N}=263)$ Jordanians youth and seniors, this study examined and compared the components of youth and the older generation value systems. Although slight differences were found between the value system components of youth and senior sample, both samples showed a similar value system structure. Generally, in addition to family orientation, both samples showed a focus on intrinsic social and political values that reflect a concern for psychological stability and independence. Nevertheless, some significant differences were found for some of the terminal values (i.e. equality, freedom, Happiness, A sense of accomplishment, Wisdom, mature love, security, and a world at peace) between the two samples. In addition, for instrumental values significant differences were also found for some values (i.e. Forgiving, Honest, and self controlled) between the two samples.

In the consumer behaviour literature, Howard (1997) suggested that terminal and instrumental values influence brand choice and product class participation. Furthermore, considering that this study shows an orientation toward family and values that enhances psychological stability, a number of implications exist for marketing managers. First, the adoption rate for new products can be predicted to be low considering that the majority of sample seems to hold conservative values. Consequently, marketing managers in Jordan should be patient when introducing new products and focus on creating acceptance on the opinion leaders of the society first. Second, promotional campaigns could focus on values that enhance the psychological stability of people and that also project a family orientation such as love, friendship, independent, intellectual or happiness. In addition, international marketers should use signs and symbols that tend to enhance these values and reflect the Jordanian culture. Moreover, previous research shows that people who focus on intrinsic values like to control every aspect of their life's including their shopping behavior and more likely to take an extra effort in their shopping activities (Homer \& Khale, 1988). As a result marketers should provide sufficient information for these types of customers to ensure they buy their brands.

Values normally carry the individual ideas to do what is right, desirable or appropriate, consequently, values play a key role in the work place especially when they align with the values of the organization (Dailey, 2012). In general, HR departments in Jordanian organizations can tailor their various policies or create new ones to reflect consideration of values most important to youths and/or seniors. This can help HR departments in terms of recruiting and attracting job applicants from these groups, maintaining them, and eventually improving person-organizational fit.

The instrumental values of clean, forgiving and ambitious were ranked in the top three in both samples. Clean, meaning neat and tidy, forgiving, meaning willingness to pardon others and ambitious, meaning hardworking 
and aspiring (Rokeach, 1973) suggest a preference by the two samples in this study to engage in modes of conduct that reflect these three values. Results in relation to the youth sample are consistent with extant literature on Millennials work values. Kuron, Lyons, Schweitzer, and $\mathrm{Ng}$ (2015) found that pre-working millennials placed more importance than working millennials on values such as interesting jobs, having good co-workers and achievement. Thus, it's important for HR departments to reflect the three values in their policies. In terms of recruitment efforts, HR departments within organizations in Jordan can each attempt to create an organizational image that reflects the neatness of the organization (in terms of its existing employees' appearance and the appearance of the physical work setting), the positive interpersonal relationships among organizational members, and a predominance of hard work which is valued by the organization. In terms of maintenance efforts, these three values can be incorporated into the codes of ethics/conduct or organizational values promoted and communicated throughout the organization. The organization can create policies that encourage and even reward employees for maintaining a certain standard in neatness, positive relationships with organizational members and exerting high levels of effort in the job. Furthermore, they can also incorporate these standards of conduct in job descriptions.

As for terminal values, the most important terminal values for youths were (in order of importance): family security, mature love, happiness and a comfortable life. According to Rokeach, (1973) family security refers to taking care of loved ones, mature love refers to sexual and spiritual intimacy, Happiness refers to contentedness, and a comfortable life refers to a prosperous one. Such values seem to suggest a preference for an end-state that closely aligns with the concept of work-life balance. This is consistent with extant literature (i.e Crumpacker and Crumpacker, 2007) that lists work-life balance as an important value for generations X and Y. Similarly, Uba, Dark, Duquette, Yendt, Gnatek, and Gallant (2012) Found that generation Y place great emphasis on achieving work-life balance, while Ng, Schweitzer, and Lyons (2010) found that millennials placed great importance on guaranteeing a satisfying life outside of work. HR departments can improve recruitment outcomes by promoting an organizational image that reflects the organizations interest in helping youth job candidates balance their working life with their professional life. Moreover, to maintain employed youths, organizations can adjust work schedule policies to reflect more flexibility in working times, organizations can provide the option of temporary and part-time work to those who prefer it instead of full-time work. In addition organizations can develop training programs to increase managers awareness of work-life balance issues and train them to consider these issues when making decisions that affect employees. These recommendations also apply to dealing with senior employees and applicants since mature love and family security were each ranked by them as one of the top three most important terminal values. Langton et al (2013) note that employees are not happy about work infringes on their personal lives. Thus, not acknowledging the importance of work life balance for employees can create problems for the manager and the organization, for example: asking an employee to go on a long business trip when one's son/daughter is sick.

Even though the findings of this study show a similar value system structure for the two samples, some values ranked highly by youths were not viewed as equally important by seniors and vice-versa. In terms of instrumental values, courageous meaning standing up for your beliefs (Rokeach, 1973) was ranked by youths as the fourth most important value. Dailey (2012) note that the values of courageous and ambitious are normally ranked very highly in the employee's value system. In relation to seniors, the fourth most important value was imaginative. That is, being daring or creative (Rokeach, 1973). The organization can respond by providing seniors with more opportunities to express their creativeness. Furthermore, with regard to terminal values, senior respondents also gave a high ranking to the terminal values of world at peace and self-respect. Rokeach, (1973) interpret world at peace as one that is free of war and conflict, and self-respect as self-esteem. These two values may indicate a preference towards end-states that reflect a work atmosphere that respectively is free of conflict and is satisfying in relation to self-esteem needs. In relation to instrumental and terminal values that were ranked as least important by each sample, organizations should also attempt to consider these values when developing various HR policies. Even though these values were ranked as least important, this does not mean they have no importance to respondents. However, because organizations operate with limited resources, it would be more sensible to direct more attention to those values that are most important to these respondents.

Finally, a number of limitations exist concerning the findings and methodology of this study as with all social sciences research. However, it still provides a good base for examining the youth issues in Jordan. First, although this study used a novel approach by collecting data from students and their parents, future research could use a more longitudinal design with a bigger sample to fully examine the changes in the value system components of the youth in Jordan. Moreover, future research could use a qualitative approach to better uncover the components of the value system of the youth considering that this study used the Rokeash value survey which uses a set of 
predetermined values. Additionally, using a sample of employees in the work place would provide new insights into the influence of these values differences on workplace performance. Additionally, future research could further examine in detail the influence of surrounding issues (e.g. foreign labor and the refugees in Jordan) on the value system changes of youth in Jordan. Consequently, it is hoped that this study shed further light on the issues facing the youth in Jordan and around the world.

\section{References}

Afisi, O. T. (2011). Globalization and value system. Lumina, 2(22), 1-12.

Bryman, A., \& Bell, E. (2015). Business research methods. USA: Oxford University Press.

Çileli, M. (2000). Change in value orientations of Turkish youth from 1989 to 1995. The Journal of Psychology, 134(3), 297-305. http://dx.doi.org/10.1080/00223980009600869

Cileli, M., \& Tezer, E. (1998). Life and value orientations of Turkish university students. Adolescence, 33(129), 219-228.

Corney, T. (2004). Youth work: The problem of values. Youth Studies Australia, 23(4), 11.

Crumpacker, M., \& Crumpacker, J. M. (2007). Succession planning and generational stereotypes: Should HR consider age-based values and attitudes a relevant factor or a passing fad? Public Personnel Management, 36(4), 349-369. http://dx.doi.org/10.1177/009102600703600405

Daghfous, N., Petrof, J. V., \& Pons, F. (1999). Values and adoption of innovations: A cross-cultural study. Journal of Consumer Marketing, 16(4), 314-331. http://dx.doi.org/10.1108/07363769910277102

Dailey, R. (2012). Organizational Behaviour (7th ed.). Edinburgh Business School.

Dessler, G., \& Al Ariss, A. (2012). Human resource management: Arab World Edition. Edinburgh: Pearson Education Limited.

Do-Quyen, L., Mohd-Zaharim, N., Hashim, I. H. M., \& Sam, R. (2014). A Comparison of Youth's Value Systems: The Case of Vietnamese Ethnic Groups. International Journal of Psychological Studies, 6(2), 128. http://dx.doi.org/10.5539/ijps.v6n2p128

DOS. (2013). "Population”. Retrieved from http://www. dos.gov.jo/dos_home_e/main/

Feather, N. T. (1975). Values in education and society. Free Press.

George, I., \& Uyanga, U. (2014). Youth and Moral Values in a Changing Society. IOSR Journal of Human Social Science (IOSR-JHSS), 19(6), 40-44.

Homer, P. M., \& Kahle, L. R. (1988). A structural equation test of the value-attitude-behavior hierarchy. Journal of Personality and social Psychology, 54(4), 638. http://dx.doi.org/10.1037/0022-3514.54.4.638

Howard, J. A. (1977). Consumer Behavior: Application of Theory. New York: McGraw-Hill.

Kamakura, W. A., \& Mazzon, J. A. (1991). Value segmentation: A model for the measurement of values and value systems. Journal of Consumer Research, 18(2), 208-218. http://dx.doi.org/10.1086/209253

Kamakura, W. A., \& Novak, T. P. (1992). Value-system segmentation: Exploring the meaning of LOV. Journal of Consumer Research, 19(1), 119-132. http://dx.doi.org/10.1086/209291

Kristiansen, C. M., \& Zanna, M. P. (1994). The rhetorical use of values to justify social and intergroup attitudes. Journal of Social Issues, 50(4), 47-65. http://dx.doi.org/10.1111/j.1540-4560.1994.tb01197.x

Kuron, L. K., Lyons, S. T., Schweitzer, L., \& Ng, E. S. (2015). Millennials' work values: Differences across the school to work transition. Personnel Review, 44(6), 991-1009. http://dx.doi.org/10.1108/PR-01-2014-0024

Langton, N., Robbins, S. P., \& Judge, T. A. (2013). Fundamentals of organizational behaviour. Pearson Education Canada.

Molgat, M., \& Larose-Hébert, K. (2010). The Values of Youth in Canada. Policy Research Initiative.

Ng, E. S., Schweitzer, L., \& Lyons, S. T. (2010). New generation, great expectations: A field study of the millennial generation. Journal of Business and Psychology, 25(2), 281-292. http://dx.doi.org/10.1007/s10869-010-9159-4

Obeidat, Z. M. (2015). Youth Unemployment in Jordan: Causes \& Solutions. International Journal of Business Research, 3(15), 77-90. http://dx.doi.org/10.18374/IJBR-15-3.7

Obeidat, Z. M., Obeidat, M. I., Obeidat, A. M., \& Xiao, S. H. (2016). Jordanians Economic Challenges \& 
Aspirations: An Empirical examination. International Journal of Business and Economics Research, 3(5), 29-37. http://dx.doi.org/10.11648/j.ijber.20160503.11

Peng, K., Nisbett, R. E., \& Wong, N. Y. (1997). Validity problems comparing values across cultures and possible solutions. Psychological Methods, 2(4), 329. http://dx.doi.org/10.1037/1082-989X.2.4.329

Penn, J. R. (1977). Measuring intergenerational value differences. Social Science Quarterly, 293-301.

Perkmann, M., \& Spicer, A. (2014). How emerging organizations take form: The role of imprinting and values in organizational bricolage. Organization Science, 25(6), 1785-1806. http://dx.doi.org/10.1287/orsc.2014.0916

Pride, W. (2008). Marketing. Cengage Learning.

Robbins, P. S. \& Judge, A. T. (2013). Organizational Behavior (Global edition) (15th ed.). Boston: Pearson.

Rokeach, M. (1968). Beliefs, Attitudes and Values: A Theory of Organization and Change. San Francisco: Jossey-Bass.

Rokeach, M. (1973). The nature of human values (Vol. 438). New York: Free Press.

Saunders, M. L., \& Thornhil, A. (2007). Research Methods for Business Students. England: Printhall.

Schwartz, S. H. (1992). Universals in the content and structure of values: Theoretical advances and empirical tests in 20 countries. Advances in Experimental Social Psychology, 25, 1-65. http://dx.doi.org/10.1016/S0065-2601(08)60281-6

Schwartz, S. H. (2007). Value orientations: Measurement, antecedents and consequences across nations. Measuring attitudes cross-nationally: Lessons from the European Social Survey, 161-193.

Schwartz, S. H. (2009). Basic human values. Paper presented at the Cross-national comparison seminar on the quality and comparability of measures for constructs in comparative research: Methods and applications, Bolzano (Bozen), Italy.

Sparreboom, T., \& Shahnaz, L. (2007). Assessing labour market vulnerability among young people. The Pakistan Development Review, 193-213.

Thompson, E., \& Arsalan, L. (2007). Preparing youth for leadership roles in changing environments: The Jordan experience. Children Youth and Environments, 17(3), 49-65.

Thomson, R., \& Holland, J. (2004). Youth Values and Transitions to Adulthood: An empirical investigation. Families \& Social Capital ESRC Research Group. Retrieved from http://www1.lsbu.ac.uk/ahs/downloads/families/familieswp4.pdf

Tsang, W. M. (1993). A study on value orientations of junior secondary school students in Hong Kong. Master of Education, The University of Hong Kong, Hong Kong. Retrieved from http://hub.hku.hk/bitstream/10722/29492/1/FullText.pdf?accept=1

Uba, M., Dark, J., Duquette, M., Yendt, M., Gnatek, M., \& Gallant, B. (2012). Generation Y and Work/Life Balance. Diunduh dari. Retrieved from http://seanlyons. ca/wpcontent/uploads/2012/01/WLB. pdf

Yasin, M. G., Shafqat, Z., \& Sattar, T. (2011). A Sociological Analysis of Determinants and Implications of Changing Value System in Pakistan. British Journal of Arts and Social sciences, 2(3), 292-309.

\section{Appendix A}

Table A1. Instrumental values means for both samples

\begin{tabular}{|c|c|c|c|c|c|c|c|c|c|}
\hline \multirow[t]{2}{*}{ Value } & \multicolumn{3}{|c|}{ Senior sample } & \multirow[t]{2}{*}{ Rank } & \multicolumn{3}{|c|}{ Youth sample } & \multirow[t]{2}{*}{ Rank } & \multirow[t]{2}{*}{ Sig } \\
\hline & Frequency & Mean & SD & & Frequency & Mean & SD & & \\
\hline Ambitious & $5.3 \%$ & 5.91 & 3.96 & 3 & $9.4 \%$ & 6.9 & 4.733 & 3 & .060 \\
\hline Broad-minded & $.9 \%$ & 9.06 & 4.80 & 8 & $2 \%$ & 9.01 & 4.731 & 7 & .936 \\
\hline Capable & $.9 \%$ & 11.2 & 4.74 & 13 & $.7 \%$ & 10.73 & 4.44 & 13 & .350 \\
\hline Cheerful & $.9 \%$ & 11.42 & 4.36 & 15 & $2.7 \%$ & 10.55 & 4.99 & 10 & .140 \\
\hline clean & $9.6 \%$ & 4.71 & 3.44 & 2 & $7.4 \%$ & 5.53 & 3.79 & 1 & .072 \\
\hline Courageous & $4.4 \%$ & 8.29 & 4.65 & 5 & $8.7 \%$ & 7.34 & 4.911 & 4 & .113 \\
\hline Forgiving & $49.1 \%$ & 3.46 & 4.06 & 1 & $30.9 \%$ & 5.62 & 5.85 & 2 & .001 \\
\hline Helpful & $1.8 \%$ & 11.04 & 5.04 & 11 & $2.7 \%$ & 10.67 & 4.82 & 12 & .551 \\
\hline Honest & $.9 \%$ & 11.77 & 4.93 & 16 & $11.4 \%$ & 8.77 & 5.39 & 6 & .000 \\
\hline
\end{tabular}




\begin{tabular}{llllllllll}
\hline Imaginative & $14.9 \%$ & 7.93 & 5.32 & 4 & $3.4 \%$ & 9.06 & 4.90 & 8 & .076 \\
Independent & $2.6 \%$ & 11.31 & 4.66 & 14 & $2 \%$ & 10.66 & 4.40 & 11 & .258 \\
Intellectual & $.9 \%$ & 11.92 & 4.39 & 17 & $2 \%$ & 12.12 & 4.59 & 18 & .695 \\
Logical & $3.5 \%$ & 8.33 & 4.38 & 6 & $3.4 \%$ & 8.31 & 4.57 & 5 & .974 \\
Loving & $1.8 \%$ & 10.79 & 4.36 & 10 & $2.7 \%$ & 11.31 & 4.71 & 16 & .359 \\
Obedient & $1.8 \%$ & 11.07 & 3.95 & 12 & $2.7 \%$ & 10.77 & 4.63 & 14 & .574 \\
Polite & $3.5 \%$ & 10.11 & 4.45 & 9 & $2.7 \%$ & 11.18 & 4.58 & 15 & .058 \\
Responsible & $3.5 \%$ & 8.62 & 5.11 & 7 & $2.7 \%$ & 9.79 & 5.14 & 9 & .068 \\
Self-controlled & $4.4 \%$ & 13.29 & 4.42 & 18 & $4.7 \%$ & 11.58 & 5.43 & 17 & .005 \\
\hline
\end{tabular}

Table A2. Terminal values means for both samples

\begin{tabular}{|c|c|c|c|c|c|c|c|c|c|}
\hline \multirow[t]{2}{*}{ Value } & \multicolumn{3}{|c|}{ Senior sample } & \multirow[t]{2}{*}{ Rank } & \multicolumn{3}{|c|}{ Youth sample } & \multirow[t]{2}{*}{ Rank } & \multirow[t]{2}{*}{ Sig } \\
\hline & Frequency & Mean & $\mathrm{SD}$ & & Frequency & Mean & $\mathrm{SD}$ & & \\
\hline A comfortable life & $1.8 \%$ & 9.31 & 4.02 & 10 & $5.4 \%$ & 8.42 & 4.85 & 4 & .104 \\
\hline Equality & $.9 \%$ & 11.52 & 4.48 & 15 & $6 \%$ & 9.080 & 4.79 & 7 & .000 \\
\hline Exciting life & $3.5 \%$ & 10.64 & 4.56 & 13 & $4.7 \%$ & 10.36 & 4.58 & 14 & .623 \\
\hline Family security & $11.4 \%$ & 7.54 & 5.30 & 3 & $11.4 \%$ & 6.68 & 5.07 & 1 & .183 \\
\hline Freedom & $3.5 \%$ & 10.80 & 4.91 & 14 & $5.4 \%$ & 9.20 & 5.03 & 9 & .010 \\
\hline Happiness & $2.6 \%$ & 9.73 & 4.94 & 12 & $16.8 \%$ & 7.46 & 5.65 & 3 & .001 \\
\hline Inner harmony & $14 \%$ & 9.12 & 5.31 & 8 & $6 \%$ & 9.087 & 5.08 & 8 & .956 \\
\hline Mature love & $46.5 \%$ & 4.52 & 5.01 & 1 & $16.1 \%$ & 7.26 & 5.22 & 2 & .000 \\
\hline National security & $2.6 \%$ & 11.74 & 4.92 & 16 & $1.3 \%$ & 10.93 & 5.10 & 16 & .032 \\
\hline Pleasure & $4.4 \%$ & 8.98 & 4.92 & 6 & $4 \%$ & 9.32 & 4.99 & 10 & .575 \\
\hline Salvation & $.9 \%$ & 12.24 & 4.62 & 18 & $1.3 \%$ & 12.4 & 4.28 & 18 & .650 \\
\hline Self respect & $2.6 \%$ & 8.35 & 4.70 & 4 & $4 \%$ & 8.95 & 4.79 & 6 & .331 \\
\hline A sense of accomplishment & $.9 \%$ & 8.85 & 5.07 & 5 & $2 \%$ & 10.20 & 4.77 & 12 & .028 \\
\hline Social recognition & $3.5 \%$ & 9.42 & 5.27 & 11 & $2 \%$ & 10.25 & 4.99 & 13 & .191 \\
\hline True friendship & $1.8 \%$ & 12.17 & 4.48 & 17 & $.7 \%$ & 11.28 & 4.84 & 17 & .130 \\
\hline Wisdom & $9.6 \%$ & 9.07 & 4.89 & 7 & $2.7 \%$ & 10.52 & 4.85 & 15 & .017 \\
\hline A world at peace & $5.3 \%$ & 8.80 & 5.41 & 2 & $10.1 \%$ & 7.33 & 4.78 & 5 & .021 \\
\hline A world of beauty & $5.3 \%$ & 9.18 & 5.25 & 9 & $5.4 \%$ & 10.19 & 5.45 & 11 & .132 \\
\hline
\end{tabular}

\section{Copyrights}

Copyright for this article is retained by the author(s), with first publication rights granted to the journal.

This is an open-access article distributed under the terms and conditions of the Creative Commons Attribution license (http://creativecommons.org/licenses/by/4.0/). 